\title{
Some Metabolic Effects of Sodium Nitroprusside in Man
}

\author{
C. J. VESEY, \\ P. V. COLE, \\ J. C. LINNELL, \\ J. WILSON
}

British Medical fournal, 1974, 2, 140-142

iodine uptake by the thyroid (Nourok et al., 1964) and with the metabolism of vitamin $B_{12}$ (Wilson and Matthews, 1966). The present study, which was designed to obtain further in-

\section{Summary}

The infusion of sodium nitroprusside during surgical operations produced plasma levels of cyanide of up to four times the control value. Plasma thiocyanate showed little change except during prolonged infusion of the drug, but total plasma $B_{12}$ tended to fall, as did methylcobalamin. Other cobalamins showed little change after nitroprusside infusion for short periods. During longer infusions the ratio of methylcobalamin to adenosyl + hydroxocobalamin fell and cyanocobalamin concentrations were high.

\section{Introduction}

The use of sodium nitroprusside as a hypotensive agent was introduced to British anaesthetic practice in 1968 (Jones and Cole, 1968). Since that time there have been further reports on its use both during anaesthesia and in the treatment of hypentensive emergencies (Taylor et al., 1970; Mani, 1971; Siegel et al., 1971). Doubts have been expressed, however, about the safety of sodium nitroprusside since its immediate metabolic products are most probably cyanide and thiocyanate (Wilson et al., 1971). In addition to their direot toxic effects it has been suggested that these substances interfere both with

M.R.C. Clinical Genetics Research Unit, Institute of Child Health, London WC1N 1EH

C. J. VESEY, M.sc., Research Assistant

Department of Anaesthetics, St. Bartholomew's Hospital, London EC1A 7BE

P. V. COLE, M.B., F.F.A. R.C.s., Consultant Anaesthetist

Department of Experimental Chemical Pathology, Westminster Hospital, London SW1

J. C. LINNELL, B.sc., Lecturer in Experimental Chemical Pathology

Hospital for Sick Children, Great Ormond Street, London WC1N 3JH

J. WILSON, PH.D., F.R.C.P., Consultant Neurologist tensive agent (to be reponted).

\section{Patients and Methods}

A saline solution of sodium nitroprusside $(100 \mu \mathrm{g} / \mathrm{ml})$ was administered by intravenous infusion to induce hypotension during anaesthesia in patients undergoing major orthopaedic surgery. The drip rate was controlled to maintain a systolic anterial pressure of $60 \mathrm{~mm} \mathrm{Hg}$ in an effort to limit blood loss. A venous blood sample $(30 \mathrm{ml})$ was taken before and immediately after the administration of sodium nitroprusside. The samples were taken into heparinized syringes, with precautions against exposure to white light, and the plasma was separated under red light within one hour. Aliquots were stored at $-20^{\circ} \mathrm{C}$ in foil-wrapped tubes for the estimation of total $B_{12}$ and plasma cobalamins. Cyanide was isolated without delay from a $5-\mathrm{ml}$ or preferably $10-\mathrm{ml}$ aliquot of the separated plasma by the method of Boxer and Rickards (1950) and estimated by the Aldridge technique (Aldridge, 1945). Plasma thiocyanate was determined by the latter method using $1 \mathrm{ml}$ of plasma deproteinized with $10 \%$ trichloroacetic acid. Erythrocyte cyanide was estimated as described elsewhere (Vesey and Wilson, 1974). Total $B_{12}$ was estimated by radioisotopic assay (Matthews $e t$ al., 1967) and plasma cobalamins by a chromatobioautographic method (Linnell et al., 1969 a; Linnell et al., 1971). Two further patients with malignant hypertension resistant to more conventional drugs received prolonged treatment by intravenous infusion of sodium nitroprusside. One patient (case 18) was a girl of 12 years suffering from cerebral haemorrhage and malignant hypertension secondary to unilateral renal disease. She received $424 \mathrm{mg}$ of the drug over a six-day period before nephrectomy. Two years later this girl was well. The second patient (case 19), aged 46 years and suffering from a dissecting aneurysm with malignant hypertension, received $2,277 \mathrm{mg}$ over a five-day period.

TABLE I-Plasma Cyanide and Thiocyanate in 17 Patients before and after Nitroprusside Therapy

\begin{tabular}{|c|c|c|c|c|c|c|c|}
\hline \multirow{2}{*}{$\begin{array}{l}\text { Case } \\
\text { No. }\end{array}$} & \multicolumn{3}{|c|}{ Nitroprusside Infusion } & \multicolumn{2}{|c|}{$\begin{array}{c}\text { Cyanide } \\
(\mathrm{nmol} / \mathbf{1 0 0 m l})\end{array}$} & \multicolumn{2}{|c|}{$\begin{array}{l}\text { Thiocyanate } \\
(\mu \mathrm{mol} / 100 \mathrm{ml})\end{array}$} \\
\hline & $\begin{array}{l}\text { Time } \\
(\mathrm{min})\end{array}$ & $\begin{array}{c}\text { Rate } \\
(\mu \mathrm{g} / \mathrm{min} / \mathrm{Kg})\end{array}$ & $\begin{array}{c}\text { Dose } \\
(\mu \mathrm{g} / \mathrm{Kg})\end{array}$ & Before & After & Before & After \\
\hline $\begin{array}{r}1 \\
2 \\
3 \\
4 \\
5 \\
6 \\
7 \\
8 \\
9 \\
10 \\
11 \\
12 \\
13 \\
14 \\
15 \\
16 \\
17\end{array}$ & $\begin{array}{l}20 \\
85 \\
75 \\
45 \\
90 \\
50 \\
85 \\
40 \\
40 \\
50 \\
45 \\
75 \\
60 \\
55 \\
60 \\
50\end{array}$ & $\begin{array}{r}4 \cdot 3 \\
4 \cdot 9 \\
7 \cdot 2 \\
5 \cdot 2 \\
4 \cdot 2 \\
7 \cdot 2 \\
1 \cdot 1 \\
8 \cdot 6 \\
7 \cdot 2 \\
10 \cdot 6 \\
3 \cdot 8 \\
3.5 \\
2 \cdot 4 \\
4 \cdot 2 \\
3 \cdot 3 \\
3.9\end{array}$ & $\begin{array}{r}86 \\
417 \\
540 \\
234 \\
378 \\
360 \\
94 \\
94 \\
344 \\
288 \\
530 \\
171 \\
263 \\
144 \\
231 \\
198 \\
195\end{array}$ & $\begin{array}{r}0 \\
5 \\
24 \\
\\
25 \\
13 \\
13 \\
\\
\\
20 \\
0 \\
80 \\
2 \\
6\end{array}$ & $\begin{array}{r}30 \\
50 \\
139 \\
237 \\
\\
\\
78 \\
36 \\
90 \\
49 \\
0 \\
56 \\
5 \\
23\end{array}$ & $\begin{array}{r}4.3 \\
9.5 \\
19.7 \\
11.3 \\
1.4 \\
11.0 \\
12.9 \\
3.4 \\
15.6 \\
16.9 \\
3.8 \\
5.3 \\
5.1 \\
11.4\end{array}$ & $\begin{array}{r}9.3 \\
5.2 \\
10.1 \\
21.3 \\
6.5 \\
12.7 \\
13 \cdot 2 \\
12.7 \\
3.7 \\
18.1 \\
8.8 \\
16.5 \\
3.9 \\
6.2 \\
4.8 \\
9.6\end{array}$ \\
\hline $\begin{array}{l}\text { Mean } \pm \text { S.E. of Mean } \\
\text { No. of Patients } \\
t \\
\text { P }\end{array}$ & & & & $15 \cdot 5 \pm 6 \cdot 3$ & $66 \pm_{12}^{17 \cdot 3}$ & $9 \cdot 4 \frac{1}{14}^{1.51}$ & ${ }_{3}^{10 \cdot 16} 1 \frac{ \pm}{16} 1 \cdot 32$ \\
\hline
\end{tabular}


TABLE II-Data on Two Patients receiving Nitroprusside for an Extended Period

\begin{tabular}{|c|c|c|c|c|c|c|}
\hline & \multicolumn{2}{|c|}{ Case 18} & \multicolumn{4}{|c|}{ Case 19} \\
\hline & $\begin{array}{c}\text { Before } \\
\text { Nitroprusside }\end{array}$ & $\begin{array}{l}\text { After Infusion } \\
\text { for } 3 \text { Days } \\
\text { with } 250 \mathrm{mg}\end{array}$ & After $200 \mathrm{mg}$ & After $700 \mathrm{mg}$ & $\begin{array}{l}\text { Before } 5 \mathrm{mg} \\
\text { OHB }_{12} \text { (I.V.) }\end{array}$ & $\begin{array}{l}\frac{1}{2} \text { hr After } \\
\mathrm{OHB}_{12}{ }^{*}\end{array}$ \\
\hline $\begin{array}{l}\text { Plasma cyanide nmol } / 100 \mathrm{ml} \\
\text { Plasma thiocyanate } \mu \mathrm{mol} / 100 \mathrm{ml} \\
\text { Red blood cell cyanide } \mu \mathrm{mol} / 100 \mathrm{ml} \\
\text { Total } \mathrm{B}_{12} \mathrm{pg} / 100 \mathrm{ml} \\
\mathrm{Me}_{12} \mathrm{pg} / 100 \mathrm{ml} \\
\mathrm{CNB}_{2} / \mathrm{pg} / 100 \mathrm{ml} \\
\text { Ado } \mathrm{B}_{12}+\mathrm{OHB}_{12} \mathrm{pg} / 100 \mathrm{ml} \\
\% \mathrm{CNB}_{12} \\
\mathrm{Me} \mathrm{B}_{12} \text { : Ado } \mathrm{B}_{12}+\mathrm{OHB}_{12}\end{array}$ & $\begin{array}{l}10 \\
4 \cdot 3\end{array}$ & $\begin{array}{r}211 \\
30 \\
630 \\
201 \\
252 \\
177 \\
42 \\
1 \cdot 1\end{array}$ & $\begin{array}{l}31 \\
14 \cdot 5 \\
1 \cdot 83 \\
460 \\
345 \\
0 \\
115 \\
0 \\
3 \cdot 0\end{array}$ & $\begin{array}{l}138 \\
32 \cdot 2 \\
13 \cdot 0 \\
570 \\
312 \\
0 \\
258 \\
0 \\
1 \cdot 2\end{array}$ & $\begin{array}{l}145 \\
50 \cdot 4 \\
32 \\
670 \\
249 \\
200 \\
221 \\
30 \\
1 \cdot 1\end{array}$ & $\begin{array}{r}152 \\
51 \cdot 9 \\
15 \cdot 7 \\
>2000 \\
>220 \\
>760 \\
>1020 \\
38 \\
0 \cdot 2\end{array}$ \\
\hline
\end{tabular}

Me $B_{i_{2}}=$ Methylcobalamin.

$\mathrm{CNB}_{12}=$ Cyanocobalamin.

Ado $B_{12}=$ Adenosylcobalamin.

*The patient was still being infused with nitroprusside.

TABLE III-Plasma Cobalamins before and after Nitroprusside Therapy in 11 Patients

\begin{tabular}{|c|c|c|c|c|c|c|c|c|c|c|}
\hline \multirow{2}{*}{$\begin{array}{l}\text { Case } \\
\text { No. }\end{array}$} & \multicolumn{2}{|c|}{$\underset{(\mathrm{pg} / \mathrm{ml})}{\operatorname{Total} \mathbf{B}_{12}}$} & \multicolumn{2}{|c|}{$\begin{array}{l}\mathrm{Me} \mathrm{B} \mathrm{B}_{12} \\
(\mathrm{pg} / \mathrm{ml})\end{array}$} & \multicolumn{2}{|c|}{$\begin{array}{l}\mathrm{CNB}_{12} \\
(\mathrm{pg} / \mathrm{ml})\end{array}$} & \multicolumn{2}{|c|}{$\begin{array}{c}\text { Ado } \mathrm{B}_{12}+\mathrm{OHB}_{12} \\
(\mathrm{pg} / \mathrm{ml})\end{array}$} & \multicolumn{2}{|c|}{ 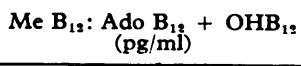 } \\
\hline & Before & After & Before & After & Before & After & Before & After & Before & After \\
\hline $\begin{array}{r}2 \\
3 \\
4 \\
8 \\
9 \\
10 \\
11 \\
13 \\
15 \\
16 \\
17\end{array}$ & $\begin{array}{r}355 \\
355 \\
275 \\
645 \\
1,030 \\
275 \\
275 \\
425 \\
535 \\
460 \\
350 \\
\end{array}$ & $\begin{array}{l}215 \\
310 \\
250 \\
680 \\
785 \\
280 \\
260 \\
345 \\
370 \\
460 \\
275 \\
\end{array}$ & $\begin{array}{r}213 \\
\\
368 \\
412 \\
69 \\
205 \\
173 \\
305 \\
329 \\
214 \\
\end{array}$ & $\begin{array}{r}129 \\
\\
306 \\
377 \\
98 \\
170 \\
124 \\
226 \\
276 \\
129 \\
\end{array}$ & $\begin{array}{r}0 \\
\\
0 \\
154 \\
22 \\
0 \\
136 \\
27 \\
0 \\
10 \\
\end{array}$ & $\begin{array}{r}0 \\
\\
129 \\
180 \\
22 \\
0 \\
90 \\
11 \\
51 \\
30 \\
\end{array}$ & $\begin{array}{r}142 \\
\\
277 \\
464 \\
184 \\
70 \\
111 \\
203 \\
131 \\
126 \\
\end{array}$ & $\begin{array}{r}86 \\
\\
245 \\
220 \\
160 \\
90 \\
124 \\
133 \\
133 \\
116\end{array}$ & $\begin{array}{l}1.5 \\
\\
1.3 \\
0.9 \\
0.4 \\
2.9 \\
1.6 \\
1.5 \\
2.5 \\
1.7\end{array}$ & $\begin{array}{l}1.5 \\
1.2 \\
1.7 \\
0.6 \\
1.9 \\
1.0 \\
1.7 \\
2.0 \\
1.1\end{array}$ \\
\hline $\begin{array}{c}\text { Mean difference } \\
\pm \text { S.E. of mean } \\
t \text { test } \\
\text { on paired data } \\
P\end{array}$ & \multicolumn{2}{|c|}{$-59 \pm 24 \cdot 6$} & \multicolumn{2}{|c|}{$-50.3 \pm 11 \cdot 8$} & \multicolumn{2}{|c|}{ $\pm 18 \cdot 2 \pm 16 \cdot 5$} & \multicolumn{2}{|c|}{$-44.6 \pm 26 \cdot 9$} & \multicolumn{2}{|c|}{$-0.18 \pm 0.18$} \\
\hline
\end{tabular}

Me $B_{12}=$ Methylcobalamin.

$\mathrm{CNB}_{12}=$ Cyanocobalamin.

Ado $\mathrm{B}_{12}=$ Adenosyl cobalami

\section{Results}

The results of plasma thiocyanate and cyanide determinations before and after nitroprusside infusion for a short period are shown in table I. In most patients there was a slight rise in plasma thiocyanate after nitroprusside infusion but the mean plasma cyanide level rose to more than four times the pretreatment level-a highly significant increase. When infusion was continued over a longer period in two patients (cases 18 and 19) there was a considerable rise in both plasma thiocyanate and plasma cyanide (table II). In case 19 estimation of erythrocyte cyanide showed that a high proportion of cyanide was taken up by the red cells. After an injection of hydroxocobalamin (5 $\mathrm{mg}$ intravenously) the erythrocyte cyanide concentrations fell sharply despite continued infusion of nitroprusside.

The results of plasma total $B_{12}$ and cobalamin estimations are shown in table III. Plasma total $B_{12}$ was significantly lowered by nitroprusside infusion though in no case did the post-infusion value fall below the lower limit of normal (180 $\mathrm{pg} / \mathrm{ml})$. The mean methylcobalamin concentration was also reduced significantly after treatment with nitroprusside and in four cases the post-treatment plasma methylcobalamin was below the lower normal limit $(130 \mathrm{pg} / \mathrm{ml}$ ) (Linnell et al., 1971). Changes in the levels of the other cobalamins were slight. In one of the patients who received a prolonged infusion of nitroprusside (case 19) there was a progressive rise in plasma $B_{12}$ and a fall in both methylcobalamin and the ratio mothylcobalamin : adenosylcobalamin + hydroxocobalamin. In both patients cyanocobalamin levels were high after several days' continuous infusion; surprisingly in case 19 the level rose most markedly after parenteral hydroxocobalamin.

\section{Discussion}

Nitroprusside has been shown to liberate cyanide when incubated with liver (Hill, 1942), blood, washed erythrocytes, plasma, and urine (Page et al., 1955; Vesey and Wilson, 1974) in vitro. Hydrogen cyanide has also been detected in cases of nitroprusside poisoning (Pharmaceutical fournal, 1936, 1948; Lazarus-Barlow and Norman, 1941; Hill, 1942). Our study, using more sensitive techniques for cyanide determination than hitherto employed, showed that cyanide was liberated in vivo from therapeutic doses. of nitroprusside. The onset of hypotension is very quick and is not thought to be related to the liberation of cyanide (Johnson, 1929; Page et al., 1955), which occurs slowly in vitro (Vesey and Wilson, 1974). Nevertheless, the plasma cyanide may reach relatively high levels in patients receiving the drug for only an hour. These levels in a number of cases exceed the levels reported for patients with tropical neuropathy due to chnonic exposure to ingested cyanide from cassava (Osuntokun, et al., 1970). The preliminary study in one patient (case 19) showed that a large amount of the liberated cyanide was in the separated and washed erythrocytes. Indeed, it can be shown that all the cyanide added to a sample of blood in vitno will pass rapidly into the erythrocytes (Vesey and Wilson, 1974). This may well affect oxygen transpon because of the inhibitory action of cyanide on carbonic anhydrase (Horejsi and Komarkova, 1960) in addition to the known effeot of cyanide (Schubent and Brill, 1968), and hence nitroprusside (Sekul et al. 1954), on cellular respiration.

Cyanide is convented to thiocyanate by the enzyme rhodanese (Lang, 1933). Thiosulphate, which acts as the sulphur donor for this enzyme, is derived from cysteine by way of $\beta$-mercaptopyruvate. The liver and kidneys contain large 
amounts of the enzyme rhodanese and it was surprising that during nitroprusside infusion plasma thiocyanate levels rose so slowly. A further enzyme, $\beta^{\prime}$ mercapopyruvate sulphur transferase, is also active in converting cyanide to thiocyanate (Fiedler and Wood, 1956). This enzyme occurs in the erythrocytes but in man the red cell activity is low and the availability of $\beta$-mercaptopyruvate is probably a further factor (Sorbo, 1957; Kun and Fanshier, 1959). This fact together with the accumulation of cyanide in the erythrocytes may explain the slow rise in plasma thiocyanate. In both animals (Mushett et al., 1952; Friedberg et al., 1965) and man (Lutier et al., 1971) hydroxocobalamin has been shown to be a potent antidote to cyanide. Probably much of the cyanocobalamin so formed is excreted (Smith, 1968) but evidently a proportion of the cyano radical is incorporated into the 1-C metabolic pool (Boxer and Richards, 1952). In practice, therefore, it may be wise to give large doses of hydroxocobalmin intravenously before and during the infusion of sodium nitroprusside. The fall in total plasma cobalamins after nitroprusside therapy is notewonthy since it has been shown that there is an inverse relationship between plasma $B_{12}$ and plasma cyanide levels (Wilson and Matthews, 1966). This fall may be a temporary event, however, since in one patient (case 19) a steady rise in total plasma $B_{12}$ was apparent and could have been due to mobilization of stored $\mathrm{B}_{12}$. The fall in plasma methylcobalamin after nitroprusside therapy indicated a possible effect on $\mathrm{B}_{12}$ distribution and metabolism. A reduction in plasma methylcobalamin levels also occurs in patients with vitamin $\mathrm{B}_{12}$ deficiency. In these cases the ratio methylcobalamin: adenosylcobalamin + hydroxocobalamin is also reduced (Linnell et al, 1969 a; Linnell et al. 1971) but in patients receiving nitroprusside therapy for a shont period there was no significant decrease in the value. In one patient receiving prolonged infusion (case 19), however, there was a fall in this ratio.

Though in the present study plasma cyanocobalamin did not invariably rise after a shont period of nitroprusside infusion it did rise to a high level in patients receiving the drug for longer periods. Individuals exposed to excess dietary cyanide or having a fault in cyanide metabolism have been found to have raised levels of cyanocobalamin (Linnel et al., $1969 \mathrm{~b}$; Osuntokun et al., 1974). In two patients (cases 9 and 13; table III) there was an initially high level of plasma cyanocobalamin with raised plasma thiocyanate levels which suggested that they were smokers.

While nitroprusside is a valuable hypotensive agent without obvious toxic effects when used for a limited period cyanide is liberated in vivo and may have adverse biochemical effects, particularly on $\mathbf{B}_{12}$ metabolism. For this reason it may prove dangerous when given to patients who have low plasma $\mathbf{B}_{12}$ levels, who have impaired liver function, or who suffer from Leber's optic atrophy. We therefore recommend that hydroxocobalamin should be given to patients undergoing nitroprusside therapy. Further work is planned to try to assess the degree of risk to the patient to determine the mechanism of nitroprusside breakdown and hypotensive action, and to develope a simple means of monitoring cyanide levels in patients receiving nitroprusside.

We gratefully acknowledge technical help from Mrs. M. Prior, and financial support from the Wellcome Trust, The Variety Club of Great Britain, the Medical Research Council, the Wade Fund, and the Joint Research Board, St. Bartholomew's Hospital

Requests for reprints should be addressed to Dr. P. V. Cole, Department of Anaesthetics, St. Bartholomew's Hospital, London EC1A 7BE.

\section{References}

Aldridge, W. N. (1945). The Analyst. 70, 474

Boxer, G. E., and Rickards, J. C. (1950). Archives of Biochemistry, 30, 372. Boxer, G. E., and Rickards, J. C. (1952). Archives of Biochemistry, 39, 7.

Fiedler, H., and Wood. J. L. (1956). Fournal of Biological Chemistry, 222, 387.

Friedberg, K. D., Grutzmacher, J., and Leudle, L. (1965). Archives Internationales de Pharmacodynamie et de Thérapie. 154, 327 .

Hill, H. E. (1942). Australian Chemical Institute fournal and Proceedings, $9,89$.

Horejsi, J., and Komarkova, A. (1960). Clinica Chemica Acta, 5, 392.

Johnson, C. C. (1929). Archives Internationales de Pharmacodynamie et de Therapie 35, 480.

Jones, G. O. M., and Cole, P. (1968). British fournal of Anaesthesia, 40, 804.

Kun, E., and Fanshier, D. W. (1959). Biochemica Biophysica Acta, 32, 338 Lang, K. (1933). Biochemische Zeitschrift, 259, 243.

Lazarus-Barlow, P., and Norman, G. M. (1941). British Medical fournal, $11,407$.

Linnell, J. C., Mackenzie, H. M., Wilson, J., and Matthews, D. M. (1969 a). fournal of Clinical Pathology, 22, 545.

Linnell, J. C., Wilson, J., and Matthews, D. M. (1969 b). Clinical Science, 37, 878.

Linnell, J. C., Hoffbrand, A. V., Peters, T. J., and Matthews, D. M. (1971). Clinical Science, 40, 1.

Lutier, F., Dusoleil, P., and de Montgros, J. (1971). Archives des Maladies Professionnelles, de Médecine du Travail et de Sécurité Sociale, 32, 683.

Mani, M. K. (1971). British Medical fournal, 3, 407.

Matthews, D. M., Gunasegaram, R., and Linnell, J. C. (1967). Fournal of Clinical Pathology, 20, 683 .

Mushett, C. W., Kelly, K. L., Boxer, G. E., and Rickards, J. C. (1952). Experimental Biology and Medicine, 81, 234.

Nourok, D. S., Glassock, R. J., Solomon, D. H., and Maxwell, M. H. (1964). American fournal of Medical Science, 248, 129.

Osuntokun, B. O., Adeuya, A. O. G., and Aladetoyinbo, A. (1970). Lancet, 2,372 .

Osuntokun, B. O. (1972). Plant Foods for Human Nutrition, 2, 215.

Osuntokun, B. O., Matthews, D. M., Hussein, H. A. A., Wise, I. J., and Linnell, J. C. (1974). Clinical Science. In press.

Page, I. H., Corcoran, A. C., Dustan, H. P., and Koppanyi, T. (1955). Circulation, 11, 188.

Pharmaceutical fournal, $(1936)$ 82, 125.
Pharmaceutical fournal, (1948), 160, 287.

Schubert, J., and Brill, W. A. (1968). Fournal of Pharmacology and Experimental Therapeutics, $162,352$.

Sekul, A. A., Booth, W. H., and Rice, J. C. (1954). Federation Proceedings, 13,403 .

Siegel, P., Moraca, P. P., and Green, J. R. (1971). British fournal of Anaesthesia, 43, 790.

Smith, E. L. (1968). Plant Foods for Human Nutrition, $1,7$.

Sorbo, B. (1957). Biochemica Biophysica Acta, 24, 324.

Taylor, T. H., Styles, M., and Lamming, A. J. (1970). British fournal of Anaesthesia, 42, 859 .

Vesey, C. J., and Wilson, J. (1974). In preparation.

Wilson, J., and Matthews, D. M. (1966). Clinical Science, 31, 1.

Wilson, J., Vesey, C. J., and Cole, P. V. (1971). British Medical fournal, 4, 116 . 